\title{
Manufactured Vulnerability: Eco-Activist Tactics in Britain ${ }^{1}$
}

This is a pre-copy-editing, author-produced PDF of an article accepted for publication in Mobilization following peer review. The definitive publisher-authenticated version vol 4 No. 1 1999 is available online at: http://www.mobilization.sdsu.edu/volumes/Volume04.html Brian Doherty

\section{Politics Department}

Keele University

Keele

Staffs ST5 5BG

United Kingdom

email: b.j.a.doherty@keele.ac.uk

\footnotetext{
${ }^{1}$ An earlier version of this article appeared in La Lettre de la Maison Francaise, 1999 (forthcoming). I would like to thank Chris Rootes and an anonymous reviewer for Mobilization for their advice and encouragement to rethink certain ideas in the earlier version.
} 
Abstract:

This article examines the development of tactics in protests by radical ecological activists against new roads and on other environmental issues in Britain during the 1990s. The technical creativity of protesters has been important in the impact of these protests and they have developed some new and distinctive tactics. In doing so they have contributed a new dimension to the repertoire of non-violent direct action which is defined here as manufactured vulnerability. This case provides much evidence which confirms the usefulness of existing accounts of how new forms of action are developed but it also suggests that tactical development in radical ecological groups is particularly likely to be influenced by latent networks of activists and cross-national diffusion. 
Since 1992 protests against new roads and other environmentally destructive projects such as quarries, open cast mines and the extension of Manchester Airport have had a significant impact on political debate in Britain. There is now widespread discussion of the need to reduce car use, major cuts have been made in the roadbuilding programme and the government is in the process of developing a new integrated transport strategy. Although not all of this change is directly attributable to the eco-activists, since the need to cut government spending and the appearance of independent reports criticising transport policy have also helped to drive these changes, the protests have been the focus of extensive media coverage and debate. For what is a small group of activists, with at any one time only, at most, around two thousand involved, ${ }^{2}$ they have achieved a major cultural and political impact.

Activist groups such as Earth First! (inspired by the US direct action network of the same name) and Reclaim the Streets are essentially networks of loosely organised local groups with no formal membership. They have no central organizations, no appointed leaders and no-one speaks for the movement, only for themselves as individuals. Such organization as exists is informal, unbureaucratic and self-consciously anti-hierarchical. Information is exchanged through newsletters and websites and at protesters 'gatherings' - temporary camps where strategic issues are debated collectively. Although the protesters resist a doctrine in the sense that this

\footnotetext{
${ }^{2}$ It is impossible to be precise about numbers. Even relatively large-scale actions such as the invasion of Whately Quarry in December 1995 only involve a few hundred activists. Around 500 activists attend the Earth First! Annual Gathering. There are probably less than this number living at protest camps at any one time, but with a high turnover of short-stay and itinerant activists the numbers of semi-permanent activists can probably be put at roughly two thousand. This figure seems to be confirmed by a report that Special Branch (Police) had identified 1,700 activists that come under the category of the radical ecological direct action movement (Sunday Express 14 January 1996). Larger numbers of supporters are mobilised for events such as the Reclaim the Streets Party on the M41 in West London in July 1996 which attracted around 7,000 participants.
} 
implies a clearly defined political theory, they do have a shared identity reflected in their frames, ethos and actions. Continuities with earlier campaigns of non-violent direct action are evident in particular in the development of protest camps as sites for mobilising opposition and expressing alternative values.

An important factor in the impact of these protests has been the use of effective and imaginative tactics, which are mainly used to prolong the occupation of sites of new developments. By prolonging evictions and creating a confrontation with the authorities which can last for weeks or even months, rather than the few hours duration of most protest actions, they have captured significant amounts of public attention. Although their aim is to disrupt construction directly and they deny that media attention is an end in itself, one of their clearest successes has been in making and sustaining a dramatic news story. At most sites eco-activists have been able to rely on the support of more conventional local campaign groups. Where the latter had tended to pursue procedural measures, eco-activists mainly concentrated on attempting to prevent construction on schemes that had already been officially approved.

\section{Theoretical Perspectives on how Forms of Protest Develop}

As a case study the British eco-activists provide much material relevant to the debates about the development of action repertoires. First, to the degree that nonviolent direct action is an established repertoire of contention (Rucht 1990), they point to the importance of learned and shared toolkits of protest emphasised by Charles Tilly (1995). In emphasising the concept of "repertoire" Tilly points to the fact that most protesters draw on the examples provided by previous protest campaigns. As a result the kinds of actions that they are likely to choose are limited by history, by the 
shared understandings of how to protest and by the values and ethos of the movement. Nevertheless, even if repertoires are limited, innovation is possible, which means that the analysis of any action repertoire implicitly raises the question of the balance between continuity and change.

Second, since they draw on examples provided by other recent non-violent direct action (NVDA) movements in Britain and other countries and have in turn inspired movements in other countries, they provide a case for the use of Doug McAdam's (1995) model of initiator and spin-off movements. McAdam aims to show that while changes in political opportunities tend to shape the emergence of initiator movements, subsequent spin-off movements are less dependent on such openings and can take advantage of new opportunities created by initiator movements. Spin-off movements are more likely to emerge as a result of cognitive or cultural factors and usually develop within the networks of earlier movements and draw upon their frames. The eco-activists can be defined loosely as a spin-off movement of the green and peace movements, but they did not draw on opportunities provided by earlier protest. Rather they emerged at a time when protest had died down and the main peace and green organizations had become more institutionalised (Byrne 1997; 1998: 424; Doherty 1998: 374-6). Nor was their emergence the result of any opening in the political opportunity structure (Doherty 1999). Rather, the initiative came from young activists dissatisfied with the limits of the bureaucratic strategies favoured by the established movement organisations. In choosing direct action they mixed existing British forms of action such as protest camps with new tactics developed by radical environmentalists in Australia.

Third, these protests support the view that when new forms emerge they do so as a result of interaction between movements and their opponents. Tilly argues that 
the forms of action chosen by movements will reflect the strategies of their opponents.In his study of the civil rights movement in the USA McAdam (1983, 1996) suggests that much of its impact could be explained by its successes in developing new tactics just as the southern authorities learned to cope with old ones. Thus, bus boycotts, lunch counter sit-ins, Freedom Rides and community-wide campaigns such as those in Birmingham and Selma, each introduced a new element into the campaign and maintained the sense of crisis and confrontation upon which the movement depended. When a new tactic was introduced, movement activity as a whole rose, not simply actions involving the use of the new tactic, but once the authorities learned how to respond to the innovation a further innovation was needed. A similar dynamic characterises the eco-protests discussed below.

It is more difficult to judge the relevance to this case of the claim that innovation and diffusion are most likely to occur during a protest wave or cycle (Tarrow 1995: 91: McAdam 1995: 235). According to Sidney Tarrow innovations are most likely to occur in what Zolberg has termed the "moments of madness" at the beginnings of protest cycles when to protesters all seems possible. Tarrow says that innovations do not transform the whole repertoire all at once, rather they are tested, amended and diffused through larger cycles of mobilisation: "It is within these larger cycles, that new forms of contention combine with old ones, the expressive encounters the instrumental, traditional social actors adopt tactics from new arrivals, and newly invented forms of collective action become what I call 'modular'. Cycles of protest are the crucible in which moments of madness are tempered into the permanent tools of a society's repertoire of contention.” (Tarrow 1995: 92).

For Tarrow a cycle of protest is characterised by heightened conflict across the social spectrum, geographical and sectoral diffusion (from center to periphery); 
increased involvement of social movement organizations; new frames of meaning and expanding repertoires of contention. A slightly different definition of 'protest waves' advanced by Kriesi et al. (1995: 113) is based on four criteria: the strong expansion and contraction of the magnitude of protest, that protest extends over a longer period of time; that it encompasses large parts of the social movement sector and that it affects most of the national territory. While it is difficult to show that Britain has been in a cycle of protest that meets either definition exactly, it does seem that protest has become more socially acceptable and that groups that would not usually be seen as typical protesters have taken part. Opposition to the poll tax spread beyond the protests of the far left to a widespread campaign of non-payment in 1990 which was particularly broad in Scotland. Since then commentators have also been taken by surprise by the intensity of support given to protest against live cattle exports by local people in Shoreham and Brightlingsea in 1995 (McLeod 1998). In 1997 and 1998 there were two large demonstrations ${ }^{3}$ by the Countryside Movement, primarily to oppose a ban on hunting but also framed as a call to urban dwellers to stop interfering in the countryside. Less visible at a national level is a spread of locally based environmental protests against new developments such as roads, housing, supermarkets and waste incinerators.

Yet, there has certainly been no "moment of madness" of the kind that occurred in Italy in 1968. Also, while there is some evidence suggestive of a rise in protest, until there is a full protest event data survey of Britain we can only surmise about the level and magnitude of protest compared with previous years. ${ }^{4}$ What

\footnotetext{
${ }^{3}$ The second of these in March 1998 attracted 250,000 people, a figure not matched since a peace movement demonstration of 1983

${ }^{4}$ According to a survey conducted by The Guardian in August 1996: "there have been more than 500 separate 'actions' against authorities in the past year. The depth of dissatisfaction with the decision-making process and the increasing tendency for
} 
appears new in the 1990s is the spread of protests involving groups that do not have previous experience of protest and the locally-based nature of much of this protest. Thus, while it is unclear whether their number and scale has in fact risen, there has certainly been a series of protests that have captured public attention and made protest appear more acceptable in British political culture. Moreover, many of the features of a protest cycle are evident: there are protests in most parts of the country, including urban and rural areas and embracing a broader range of social groups than perhaps ever before in Britain. In most cases these protests begin outside established social movement organizations, but the latter tend to recover their position to become involved later. ${ }^{5}$ There has also been some diffusion of tactics from innovators to other social groups, but cultural and practical barriers mean that some forms of action remain the preserve of eco-activists.

\section{The Dynamic of Protest and the Evolution of Tactics}

Protests at road and other construction sites are a form of siege warfare.

Protesters occupy a site and build defences in trees, houses, or underground tunnels.

people to resort to direct action to assert what they say is their rights is believed to be unique in post-war Britain (Vidal and Bellos 1996)." The Police Review 21 March 1997 stated: "In the last five years, the Metropolitan Police has had to deal with 510 separate policing operations [in London alone] classified as being concerned with environmental groups - and the trend is upwards (Quoted in Anon 1997c: 136)." ${ }^{5}$ This is most clear in the case of the main environmental campaign organisation Friends of the Earth (FoE). Having been taken by surprise by the growth of environmental direct action, FoE began to make contact with eco-activists and to transfer resources into supporting local grassroots campaigning from around 1994. The campaign to prevent a ban on hunting did lead to a new organisation with a deliberately broader remit than simply opposing the ban - The Countryside Movement - but this group appears to be unstable and likely to disband now the overwhelming priority of defeating a ban on hunting has been achieved. Compassion in World Farming assisted the protest against live exports (Mcleod 1998) and its success in mobilising media coverage and protests at docks and airports in 1994 undoubtedly helped to frame the issues for the local protesters who blockaded trucks at Shoreham 
The besiegers outnumber the occupiers, and have greater resources. One of the principal weapons of the besiegers is the cherry-picker crane, which can hoist bailiffs to pluck protesters from trees, rooftops or rope walkways at heights of up to 200 feet. Successive protests have produced new techniques for resisting the besiegers, to the extent that, when the time comes for an eviction, great hopes are invested by protesters in the effectiveness of specific forms of obstructing eviction. Yet, while the eviction represents the culmination of the campaign, it is not the only event of significance. Aside from the considerable amount of work invested in building site defences there are also forays into the territory of their opponents. Contractors' offices are occupied and shareholders' meetings are disrupted. Also, since 1995 the campaign has been taken into city streets with surprise actions to reclaim urban space from traffic.

Three factors have influenced the development of tactics by protesters. First, situational factors such as the terrain and also the nature of the local community shape the choices available and influence the values appealed to. Open chalk downland such as at Twyford Down (Hampshire) provided fewer opportunities to defenders than the woods at the M65 in Preston (Lancashire). The destruction of designated Areas of Outstanding Natural Beauty and wildlife habitats was emphasised at Newbury and other rural sites, while the social destruction of an east London community, bisected by a road intended to bring commuters from outside into central London more quickly, was the main issue for those opposing the M11 Link.

Second, the values of protesters also influenced tactical choices. At Twyford, the Dongas Tribe (who named themselves after the medieval trackways that crossed the Down) used dragon symbols, and drew boundary circles, invoking the power of 
magic to defend their site. It was argued by some in this group that rediscovering indigenous Celtic and earth-based spirituality would help to restore the balance of nature. Adopting a tribal identity, and in the case of the Dongas, even a nomadic way of life, was also a means of situating themselves in the global struggles of indigenous peoples against ecological destruction. After their eviction from Twyford many of the Dongas lived in mobile camps of "benders" (tents made of hazel branches and tarpaulins), carrying possessions on carts and donkeys along old trackways, so minimising their contamination by modernity.

There was a distinct anti-urbanism evident among some other eco-activists. Some contributors to the Earth First! journal, emphasised the need to escape from the spiritual desolation of cities. This influenced the choice of tactics. In the M11 campaign some of those squatting houses in Leytonstone could not understand the "hippies"” obsession with sitting in trees. The squatters believed that "it made far more sense tactically to occupy houses than trees." Furthermore, "once there were other rural campaigns to go to (first Bath, later Preston) the 'tree people' tended to move away from the urban wilderness of east London, particularly once the 'bender site' had been destroyed in July 1994" (communication from activist with Reclaim the Streets). Trees also had an expressive role. They were given personalities, and some at Preston (M65) left before the eviction rather than see "their tree" destroyed. Tree sits have been a feature of environmental direct action in Australasia and Northe America since at least the late 1970s but even the most recent New World manuals for ecoactivists do not include tree houses, as distinct from platforms (DAM Collective 1997). Tree houses had considerable defensive value. It is difficult to be caught by surprise action by evictors in a tree house. They also provide a base for storing 
supplies and allow those less experienced at climbing a means of participating in delaying eviction. And the defences of tree houses became more sophisticated as the protests developed. ${ }^{6}$ The eviction of the tree houses at Newbury and Manchester saw desperate and emotional confrontations in which protesters used flour, urine, and disinfectant, as well as staves with rubber hoses, designed to impede chainsaws, to hamper the actions of bailiffs.

In contrast, the adoption of the street party as a tactic by Reclaim the Streets drew on a mix of sources from dance culture of rave parties to anarchist traditions of popular participatory revolts in which the politics of urban space and community were more central than the natural environment: "The privatisation of public space in the form of the car continues the erosion of neighbourhood and community that defines the metropolis. Road schemes, business 'parks', shopping developments - all add to the disintegration of community and the flattening of locality...To rescue what is left of the public arena, to enlarge and transform that arena from a selling and increasingly sold space - from controlled locality to local control - is fundamental to the vision of reclaiming the streets (Anon 1997e: 4-5)." For RTS the street became a metaphor for the communal sphere embracing "dwellings, people and interaction" in contrast to the sterile tarmac of roads. Pointing to the danger that the street party as a festival might become a caricature of itself RTS argues that the street party could develop into a regular political space: “The participatory 'party' or 'street' meeting could be a real objective for the future street party. For an event that goes beyond temporarily celebrating its autonomy to laying the ground for permanent social freedom. Discussion areas, decision-making bodies, delegates mandated to attend other parties;

\footnotetext{
${ }^{6}$ For a description of the technical rationale for more sophisticated tree house defences, capable of dealing with improved eviction techniques, see the account of the building and eviction of the Battle Star Galactica at Manchester Airport, Anon 1997a.
} 
in short the formation of a 'body politic', could all happen within the broader arena of the street party (Anon 1997d: 5)." For RTS “the street party of street parties" is therefore an anarchism which poses a direct challenge to the state and capitalism. It is not simply roads and cars but the system that produces them that must be opposed and the street party is a means of doing this appropriate to the modern era.

The third factor that shaped the development of tactics was the ability of opponents to adapt to earlier tactics. The main initial successes at Twyford Down in 1992 and 1993 were in disrupting construction work through surprise invasions of the site. Under safety at work legislation the builders were forced to stop work, and on many days protesters were successful in climbing on bulldozers and chaining themselves onto vital machinery. In the end such tactics could be countered by increasing the number of security guards. But protesters continued to use this tactic with some success in delaying the progress of machinery and, by increasing the level of security required, they were increasing the costs of the road as well as keeping the road in the public eye.

However, greater delays could be achieved by occupying buildings and trees which was the next tactical move by protesters. ${ }^{7}$ New defences at such sites meant that even the use of overwhelming numbers by the authorities did not guarantee easy success. The eviction of Claremont Road, the last main squatted site on the path of the M11 (London), in November and December 1994 was carried out by 700 police, 400 security guards and 200 bailiffs. Nevertheless, the eviction took 4 days during which the 500 occupiers were able to make themselves a major news story and score tactical successes, such as maintaining power supplies to the occupiers through a secret tunnel

\footnotetext{
${ }^{7}$ Tree houses were first used at Jesmond Dene in Newcastle in 1993.
} 
beyond police lines. ${ }^{8}$ A scaffolding tower constructed on the rooftop of one house allowed one protester to delay the evictions single-handedly for a further day.

Whereas by the time of the evictions at Claremont Road protesters had accepted that the houses would be demolished, when evictions began at Newbury in January 1996 there was greater optimism that skilled defences would delay the progress of road building significantly and the hope that they would buy enough time for procedural measures to halt construction. The evictions of the 28 camps at Newbury took 11 weeks and became a regular feature on TV news. In one sense this was a success, since the theatre of direct action forced awareness of the depth of feeling expressed by the protesters, and protesters themselves were conscious of this effect of their action. One M11 protester said: "Direct action is a theatre. The media like that...Direct action is totally direct: it's real and not just mediated politics. The agreement on non-violence is ritualised. It's like a performance"(Carey 1995: 22). but in other respects the dramatic quality of the evictions reinforced the sense of distance. The medieval character of the battle, with massed lines of security guards with bright tunics moving through the mist, cherry pickers like siege engines manoeuvring slowly towards their goal, and a phalanx of security guards and knights in the form of police on horseback, reinforced the sense of dislocation from everyday life. While more conventional groups of locals were often portrayed acting in support of the eco-activists, they were usually on the fringes, reinforcing the image that ecoprotest had become a technically skilled form of action which not only required a difficult lifestyle but also a degree of professionalism that should not be attempted by amateurs. The evictions of the trees and tunnels at Fairmile in Devon in January 1997

\footnotetext{
${ }^{8}$ One activist commented proudly: "The phenomenal thing is, Amsterdam was the longest eviction before this one at two and a half days and they had AK47s and
} 
and Manchester in May were also represented as a battle between specialists.

Moreover, the authorities were able to reduce some of the visual impact of the eviction by establishing cordons around both sites which meant that neither supporters nor reporters were able to see much of the drama of the eviction.

The Government also tried to harass road protesters through the courts but initially this back-fired badly. Attempts to sue protesters at Twyford Down for the costs of the police action were unsuccessful and when several Twyford protesters were sent to jail for breaking injunctions against protesting they received significant supportive media coverage and a visit from the European Environment Commissioner, Carlo Ripa de Meana. However, protest also provided opportunities to justify repressive legislation. The Criminal Justice Act (1994) introduced new restrictions on the right to protest which made it possible for the police to prosecute protesters for trespass as a criminal offence. The most effective technique used by the authorities was the regular use of injunctions to stay away from the site of roads as a part of bail conditions. This kept many hundreds of protesters, once arrested, off site. Surveillance also played an increasing role as protests developed. From 1992 onwards the Government employed a private detective agency to gather evidence about protesters. Since the information gathered was not often used in prosecutions it was assumed by protesters that the presence of camcorders and surveillance teams was intended mainly to intimidate. The same was true of the raid on the Offices of Reclaim the Streets in London in August 1996. Rather than try to arrest the 7,000 who joined in the previous month's street party on the M41, the police waited to target the main organisers. They took away a computer from the group's office and threatened an activist with conspiracy charges. In March 1996 the Association of Chief Police 
Officers announced that they would use anti-terrorist squads to step up surveillance of environmental activists. Despite the lack of any serious violent incidents at any roads protests the spectre of environmental terrorism was being used to justify the need for domestic intelligence spending. ${ }^{9}$

By 1998 new approaches taken by the authorities threatened to undermine the effectiveness of protest camps. The eviction of camps at the site of a road to a quarry in Somerset occurred without the usual legally required notice being given because the police were acting on a new interpretation of an old law and took protesters by surprise. At Bangor in North Wales the police exerted painful pressure on protesters to force them to remove themselves. If these changes in police tactics are upheld by the courts this threatens the viability of long-term site occupations. In response, activists have begun to shift to new tactics. In sabotaging fields where genetically modified foods are being grown, they have established deliberately short-term camps where the focus is on educating the public rather than resisting eviction.

\section{Technical Interaction}

The clearest examples of innovation were in the development of techniques for resisting and delaying eviction. Some of these techniques of similar variants had previously been used by eco-activists in Australia, but they were novel in Britain. The evolution of these techniques was also affected by the ability of the authorities to react

the beauty of it." (Carey 1995: 18)

${ }^{9}$ A detailed review of police surveillance and intelligence gathering tactics is given in a recent issue of the Earth First! journal Do or Die (Anon 1997c). In November 1997 three activists were sentenced to three years in prison for conspiracy to incite illegal direct action by reporting and advertising actions and providing materials that would encourage such action in two magazines; Green Anarchist and the Animal Liberation Front Support Group Newsletter. Although both newsletters were on the fringes of the eco-direct action network, the trial was recognised by some activists as having important implications for eco-activists (Anon 1998c). 
and adapt. The most successful of the technical devices used by protesters were lockons, walkways, and tripods. To 'lock-on' protesters placed their hand in a tube wide enough only for their arm and clipped their wrist onto a metal bar at the other end of the tube. When the bar and tube were embedded in concrete it became very difficult to move them. At Claremont Road (M11, East London), for instance, people who appeared to be lying on mattresses in the road were actually locked-on to concrete in the road itself and were able to delay the advance of cherry-picker cranes for several hours. Lock-ons could even be used in trees. An empty oil barrel was hoisted into the tree and then filled with concrete and lashed down with a tube inserted to allow the protester to lock-on. Pneumatic drills had to be used to extract the tube. However, whereas at first this often took hours, as bailiffs became more experienced and prepared they were able to break lock-ons more quickly. In response, protesters adapted their own tactic, adding rubber, metal and glass to hamper the drills.

Walkways were ropes strung at a height between trees or houses to allow protesters to move around above ground level. Once an eviction began, some protesters would move onto the walkways and climb up and down, sometimes without harnesses, to avoid being plucked from them. There were many cases when the ropes were cut with protesters still on them and on several occasions protesters fell. However, the most effective counter to walkways and to tree climbers was the introduction of a specialist team of paid climbers by the bailiffs. The recruitment of climbers caused considerable controversy in climbing clubs, but the Sheffield-based group were used regularly after the evictions at Stanworth Woods near Preston in 1995. The battles in the tree tops at Newbury were dangerous and on some occasions violent, as protesters, who included some famous in climbing circles themselves, were chased across trees until eventually removed. 
Tripods were scaffolding poles of around 10 meter length, formed into a tripod and clipped together, from which protesters could be suspended. To move them risked causing the protester serious injury. They were first used to block bulldozers by rainforest campaigners in Australia in the early 1980s. In Britain, their first use was by the urban-based group Reclaim the Streets to block traffic in the rush hour in Greenwich (South East London) in 1995. They became a regular feature of Reclaim the Streets' actions across the country because they provided a portable and rapidly erected barricade.

The final general technical innovation was the use of tunnels. These do not appear to have been used by protesters elsewhere prior to their use in Britain. The first extensive network of tunnels was at Fairmile in Devon in the route of the A30. The effectiveness of the tunnels depended in part on the nature of the ground. By lockingon underground, protesters hoped to make it impossible for the evictors to bring up heavy machinery, based on the risk of the tunnels collapsing. At previous evictions at Newbury tunnels were seized before protesters could get into them, and at Trollheim, another protest camp on the A30 route, protesters had been evicted from tunnels within hours, but the evictors had taken considerable safety risks, cutting off air and communication for several hours and moving heavy machinery close to the tunnels, which protesters were able to exploit for publicity. The network at Fairmile was more extensive and sophisticated than elsewhere, and three protesters remained in the tunnel for almost seven days.

The limitation of tunnels is the same as that of other methods used by this movement: their success depends upon the risks taken by the protester and the care taken by evictors to avoid causing injury. As experience of evictions developed, the bailiffs and police became less cautious in using force and more skilled at overcoming 
the defences relied on by protesters. Whereas earlier the technical devices developed by protesters had created confusion and secured delay, by 1997 the authorities were able to take them into account in their planning. Contractors at Manchester Airport included the cost of the protests in their calculations. Moreover, each new device has required protesters to take new risks. Only the most committed activist would take the deliberate risk of locking-on within a homemade tunnel. At Manchester in May 1997 around 150 activists were on site at the time of the evictions. There were more tunnels and deeper and more complex defences than previously and the evictions took longer. The Manchester Airport protest combined most of the technical know-how developed by protesters, with lock-ons, walkways, tree houses and tunnels all used to make the eviction a lengthy and expensive process. In once case a protester placed a noose around her neck attached to a tunnel door. The final protester to leave a tunnel had spent 17 days underground and was dug out after a tunnel wall collapsed on him and the specialist caver evicting him. Although to some protesters such risks are too great, because the campaign has no rules banning excessive risks, the level of risk is an individual's choice.

One way of defining the novelty of the tactics used by eco-activists is to point to the manufactured character of their vulnerability. The deliberate use of vulnerability has been central to the moral force of all non-violent direct action but the eco-activists were not in themselves vulnerable to any major violence from opponents or the authorities, nor could they hope to provoke or expose it. Blockaders in liberal democracies in the past have usually been removed quickly by police and such tactics have become too routine to be effective, particularly when carried out by familiar protest groups. Eco-activists have attempted to create their own, new, form of vulnerability. If the authorities are not going to use violence on a scale sufficient to 
shock the public, how can protesters resist in a way that maximises their effectiveness but also exposes the contrast between the force used by the authorities and protesters' moral superiority? Eco-activists in Britain and elsewhere have used technical devices to manufacture their own dangers in order to make their bodies vulnerable. The use of tools is therefore more than simply a technical game; it is essential to the dual aims of making power visible by prolonging its exposure and attempting to change government policy directly. In Britain these tactics allowed protesters to achieve success in two ways. They could delay evictions for days and even weeks, in contrast to the few hours that it usually takes to remove a sit-down blockade, substantially increasing the economic and political costs of road-building, and they were able to carry out a sustained performance of their own moral commitment for a media and public captured by the epic quality of the confrontation.

Some of the forms of actions adopted by the British eco-activists are less new and more inclusive than others. In particular, the actions that take place away from the defence of a site for development have allowed for wider participation. Critical mass bicycle rides which slow down urban traffic by filling the roads with bikes have a long tradition internationally, but have become widespread for the first time in British cities in recent years because of initiatives taken by the eco-protest direct action groups.. The actions oriented to reclaiming urban streets, do not at first sight appear novel because they are a variation on the tradition of barricades (Traugott 1995), but this is misleading, because the tripods used are a very new form of barricade. Whereas previously barricades provided protection for protesters now the tripod exposes the vulnerability of the protester. It does not oppose force with force, but places the responsibility for the protester's safety in the hands of the authorities. One of the effects of street parties and some of the other urban actions was that larger 
numbers of people were able to join in protest actions than at sites being defended against evictions, without relying on the prior mass mobilisation sought for traditional demonstrations. Indeed, when traditional demonstrations were organised there were confrontations with the police which resulted in bad publicity for the demonstrators. The demonstration against the Criminal Justice Act in October 1994 and the joint Reclaim the Streets, Liverpool dockers and other strikers demonstration in London in April 1997 were largely non-violent and non-confrontational, but small scale violence captured the attention of the media.

\section{Continuity, Diffusion and Change}

In Britain the tactics used by eco-activists appeared innovative, but new repertoires do not emerge spontaneously. In this case prior British traditions of protest and techniques borrowed and adapted from other eco-activist movements were important factors as well as genuine tactical inovations such as tunnels. As we would expect, there are inherited elements in the frames, organizations and forms of action adopted by the contemporary eco-activists. First, as research by Derek Wall (1997) has shown, interviewees among the key founders of the Earth First! network all had prior political experience in green or peace movement groups. Those with previous experience of NVDA from the peace movement played an important role in passing on lessons to the younger founders of Earth First! But this is a two-way process. After a lull in the early 1990s, direct action at military bases, weapons factories and arms fairs has revived in recent years partly because of the involvement of eco-activists. The Genetix Snowball campaign against genetically modified food has also revived an earlier Snowball campaign by the peace movement in the 1980 s which was intended to fill the courts with civil protest cases. Another influence, on the more 
militant eco-activists in particular, was animal rights activism. Many of those with a background in animal rights protest were among the most hostile to what was seen as the dogma of non-violence. A third source of influence came from New Age travellers who had become more politicised in response to the increasing efforts of the authorities from the mid-1980s to drive them off the road. A fourth influence, most obvious in the case of street parties, was rave culture -based on parties in temporarily squatted buildings. The first RTS street parties were influenced by the alliances formed with rave organisers who were targeted along with eco-activitss by the 1994 Criminal Justice Act. ${ }^{10}$ The first three of these networks (and to some extent also the fourth (McKay 1996)) shared an anarchistic frame, hostile to state power and emphasising the importance of taking responsibility for challenging the political and social system through direct action. However, the importance of the peace movement may outweigh the others particularly in the commitment of eco-activists to nonviolence. It was the peace movement more than the other sources of influence that provided the most relevant example of how to combine direct action and radical political ideas.

The eco-protest camps are in some respects a continuation of the peace camps of the 1980s (one peace camp at Faslane in Scotland has been in continuous existence since the early 1980s). The women's peace camp at Greenham Common became the best known of the women-only and mixed camps and much of the ethos that Sasha

\footnotetext{
${ }^{10}$ In analysing the sources for the street party RTS reveal their historical selfawareness by placing it in a broader tradition: "The mobilisation, assembly and movement of large crowds draws on skills from roads protests. The use of sound systems draws on dominant popular culture whereas the initial inspiration for street parties certainly reflects the parties of the Claremont Road days. However, RTS have retrospectively also realised that their roots lie deeper in history. The great revolutionary moments have all been enormous popular festivals-the storming of the Bastille, the Paris commune and the uprisings in 1968 to name a few. A carnival
} 
Roseneil (1995) describes in her analysis of Greenham can also be said to be dominant in the 1990s eco-protest movement, particularly the individualist character of protesters, notable especially in the strong emphasis on autonomy and taking personal responsibility for action. Peace camps provided crucial lessons about occupying space and using that space to create an alternative community. There are also, of course, important differences between the 1980s peace camps and the 1990s eco-activists not least of which was the importance of women organising autonomously at Greenham. The lack of attention given to gender issues among ecoactivists has been noted by commentators (Hunt 1995; McKay 1998: 49-50) and activists have pointed to occasions when women left camps because of the men's lack of awareness of patriarchal domination (Anon 1998e; Anon 1997a; Donga 1996). ${ }^{11}$ Attitudes to non-violence also appear to be somewhat different. There seems to be less concern with non-violence as an end in itself among eco-activists and a clear consensus that damaging property can be justified. In general the rejection of violence appears to be strategic and many eco-activists resist what they perceive to be the more dogmatic elements of the philosophy of non-violence. ${ }^{12}$

Indigenous British networks and cultural examples therefore provided important resources for eco-activists but activists "adapted and interpreted" (McAdam

celebrates temporary liberation from the established order; it marks the suspension of all hierarchy, rank, privileges, norms and prohibitions. (Anon 1997e: 3)."

${ }^{11}$ As one woman activist commented: "protest camps can be one of the most chauvinistic, domineering and belittling experiences for a woman to be in. Maybe it's the extremely unbalanced ratio of men to women on site that makes the leering fire lit eyes of the cider induced hippy a very bothersome experience. For starters there seems to be this assumption that women can't climb, can't put up walkways and that their tree houses need the stern eye of the more experienced male cast upon them before anyone would dream of having a smoke in them (Anon 1998e)."

${ }^{12}$ Another difference arises over the question of accountability. There is stronger loyalty among peace activists to taking public responsibility for direct action to the extent that many pledge not to evade arrest. Similar debates have occurred among 
1995: 229) this heritage. In this sense they fit McAdam's description of a spin-off movement. However, it is also important to stress that the height of peace movement activism was in the early and mid-1980s. While peace movement NVDA continued after this time - and there were other groups such as hunt saboteurs where activists could have had experience of direct action - from the accounts given by activists and because of their youth - most are in their early twenties - it seems probable that most did not have personal experience of direct action prior to their involvement in ecoprotests. Only the anti-poll tax movement of the late 1980s provides a bridge between the large-scale NVDA of the early and mid-1980s and the eco-direct action of 1991-2 onwards. Yet, while a major anti-poll tax demonstration developed into a riot in 1990, for the most part anti-poll tax activity was indirect - based on the strategy of withholding payment. It is only in certain areas such as Glasgow that there is a clear link between organization against the poll tax and anti-roads campaigning.

This suggests that the category of spin-off movement may need to take into account not only the influence of visible initiators of a protest cycle but also more long-term and less visible influence from apparently latent networks of activists. In this case the eco-activists drew on the counter-cultural networks and traditions of nonviolent direct action that had become established in the early 1980s and remained in existence despite the decline in NVDA in the late 1980s and early 1990s (Maguire 1992). It was these activists who assisted in the revitalisation of non-violent direct action in the early 1990s and the counter-culture that they had maintained that provided the anarchistic frames that the protesters used to make sense of their actions.

McAdam (1995; McAdam and Rucht 1993) also notes that the example of diffusion from the US to the German New Left suggests that spin-off movements can 
arise through cross-national diffusion. The second major feature of this repertoire is its transnational character. As noted, some of the technical devices used by British protesters such as tripods were previously used in Australia. The nature of the lock-on also seems to have developed over time. The Suffragettes are still remembered for chaining themselves to railings but until the invention of the bicycle D-lock bolt cutters proved effective in removing chains quickly. In US and Australian ecoactivists used the new bicycle locks to chain themselves to machines, but this tactic was only effective on mobile actions and when contractors did not have hydraulic bolt croppers. Concrete lock-ons have become common for eco-activists in Britain and the New World. The exchange of tactics is so rapid that it is difficult to trace a clear path. Whereas in the late 1980s technical manuals such as US Earth First!'s Ecodefense reflected the emphasis of its activists on sabotage, the Earth First! (USA) Direct Action Manual and the Australian Inter-Continental Deluxe Guide to Blockading and the British Road Raging ${ }^{13}$ overlap considerably and make reference to each others' tactics. Nevertheless tactics remain easier to diffuse than identities. There are points in common between eco-activists in all three countries, such as the rejection of formal organisation, and a common (but not universal within any one country) interest in paganism. But British activists have concentrated more on public protests and relatively less on sabotage, and are less concerned with the defence of wilderness, or with issues of deep ecological philosophy. Issues of global political economy are more important in the discourse of British activists ${ }^{14}$ while there is much less debate

action and those taking a more militant line (Doyle 1994).

${ }^{13}$ This can be downloaded from the Internet: http://www.hrc.wmin.ac.uk/campaihns/ef/rr/index.html.

${ }^{14}$ An extract from a Reclaim the Streets leaflet can illustrate this: 'The struggle for car free space must not be separated from the struggle against global capitalism, the streets are as full of capitalism as of cars and the pollution of capitalism is much more insidious.' 
about issues of race and gender than in North America and Australia. In that sense, though inspired by overseas examples, British activists remain different from their New World counterparts.

The high media profile of British eco-protests and the ease of travel within Europe has assisted the diffusion of the eco-activist repertoire directly through activist networks to other counties in Europe and beyond. British activists have been visited by German, Scandinavian, Dutch, Belgian, Spanish, Italian, Polish, American and Canadian activists keen to take part in the British protest and to learn the techniques of tunnelling, lock-ons and tree defences. German radical ecology activists set up groups inspired by British Earth First! in 1994 and anti-road tree camps in Freiburg and Thüringen in 1996. ${ }^{15}$ A Dutch Earth First! group was formed in 1997 under the title Groen Front! by activists who had been at British protest camps who then formed a protest camp against the building of a new harbour outside Amsterdam. ${ }^{16}$ In the same year Irish Earth First! groups established camps using techniques borrowed from Britain. There have been Reclaim the Streets parties in Sydney, Amsterdam and Helsinki and Polish police were said to be non-plussed by lock-ons and tree houses used to obstruct a new road in 1998. The British Earth First! journal devotes considerable space to news from "other islands" and British activists see themselves as part of an international direct action movement. There is also evidence of organised efforts to diffuse this knowledge. In October 1997 a conference of anti-roads activists

\footnotetext{
${ }^{15}$ A German activist estimated the numbers involved in the radical ecology network at around 500, but spoke of obstacles to building the movement because of the tendency of left-wing greens to see radical ecology as potentially ecofascist (Anon 1997b).

${ }^{16}$ An account of the formation of this group includes the following passages: "It all began over a year ago when the Dutch direct action movement Groen Front! started, based upon the ideas of the British Earth First! Several Dutch activists had been over to the action camps at Newbury, Fairmile and Manchester to learn from their British
} 
in Lyon brought together 65 activists from 21 countries who shared tactics and carried out a Reclaim the Streets action. While the British eco-activists now appear to be at the centre of this tactical innovation, they in turn owe much to Australian activists and admit that they can learn from the experience of German anti-nuclear protesters in stopping convoys.

The tactical repertoire of eco-activists is therefore a complex process of diffusion both within national counter-cultural networks and cross-nationally. This repertoire appears to have spread because manufactured vulnerability can be useful wherever the police, developers and authorities are constrained by public opinion in their use of force against eco-activists. Like the sit-in in the 1960s, the use of technically manufactured vulnerability to prolong a site occupation seems to have become the signature form of action for eco-activists cross-nationally.

\section{Conclusion}

In Britain the tactics defined here as manufactured vulnerability were at first unexpected and caused confusion but have now become part of the cultural fabric and the authorities have learned how to deal with them more effectively. In this sense it can be argued that manufactured vulnerability has elements of modularity (Tarrow 1994). However, the tactics used by eco-activists are seen as the property of a specialised sub-culture and it seems likely that this will remain the case, particularly in the case of protest camps. These have become part of an NVDA tradition but are unlikely to be appropriate to other groups, first because they are so situationally specific - as a means of establishing as permanent as possible an occupation of a space and second, because the skills and time that they demand are too difficult for 
most older people and those with family and work commitments to take up. This has not generally been the case with other forms of non-violent direct action. It is true that most forms of high risk and confrontational non-violent direct action are mainly carried out by the young and able-bodied, but most are short-term protests of a few hours and older people or those with major commitments outside the campaign are more able to take part. The tactics of eco-protest, dependent as they are on maintaining a full-time presence, technical skills which take time to master and are mainly learnt by living on site, and high levels of personal discomfort and risk, seem unlikely to be used by other groups in society. In that sense there is a professionalism inherent in manufactured vulnerability which demands full-time activists.

However, that does not mean that there has been no tactical diffusion to other groups. In August 1987 Earth First! Action Update reported: "Increasing numbers of community groups and local residents are ringing local EF! activists asking them for help with campaigns. Rather than parachuting in a small, already overstretched rentamob, we need to be able to pass on our skills and experience to other groups." Opponents of a housing development in Yorkshire were advised by a local ecoactivist on how to get legal recognition for a site occupation forcing the developer to take court action to evict them. ${ }^{17}$ Eco-activists also undertook direct action with

activists to different cities in the Netherlands (Anon 1998e: 97)."

${ }^{17}$ Activists at the N11 anti-road building camp in Ireland have been contacted by local groups in Bray and Santry wanting to know how to prevent new housing. In general, however, the reports that suggest that other groups are about to take up eco-activist tactics tend to mean only the kind of tactics that can be used quickly and which have often been used by other NVDA groups. For instance In May 1997 the Pensioners' Rights Campaign blocked traffic on Leicester's main street and in September the same group blocked the Humber Bridge and Women's Institute members in North Yorkshire planned to take direct action against plans to erect new electricity pylons. But while they intended to set up a telephone tree a spokeswoman "insisted that members would not be embracing true eco-warrior behaviour by digging tunnels or building tree houses" (Hall 1998). The campaign to preserve hunting with hounds provides another example. Its spokesman Lord Apsley was reported as 'threatening to 
groups of sacked workers, most notably the Liverpool dockers, using their climbing skills to occupy gantries and office roofs. Thus even if the more technically demanding tactics remain the preserve of a specialised group, eco-activists can still play a role in diffusing other tactics to new groups. And as we have seen, the other notable aspect of the diffusion of this repertoire is its international character. British activists learned from US Earth First! and Australian anti-rainforest campaigners and the tactics developed in Britain have been used subsequently in other parts of Europe.

It may be that tactics assume a larger role in this movement than in others because by living at a protest camp in what is more or less a permanent and public state of confrontation much of what protesters choose to do is related to tactical choices. In his account of the Newbury protests, Merrick (1997) described continuous camp fire conversations about tactics, and saw the inability to talk about anything else as one of the signs of 'losing it'. This campaign might therefore be argued to be unusually tactically obsessive but also unusually tactically creative.

\section{REFERENCES}

Anon. 1997a. "Life on the Battle Star: a Personal Account." Do or Die: Voices from Earth First! 6: 82-86.

adopt the same direct action tactics of eco-warriors like Swampy and Animal if Parliament bans hunting. "When it comes down to it I believe [we] would be prepared to go out and protest by blocking roads. There are a lot of us, and we are a very well disciplined bunch. I believe we would be prepared to follow orders. A welldisciplined force is a lot more frightening than a rabble...We have all seen the French burning things and blocking roads, and naturally there was talk of these things." "Hunt Peer Sees Fear Campaign' The Guardian July 18 1997. However, blocking roads is not the same as occupying a site and transforming it into a defended encampment. It is difficult to imagine hunters being able to sustain such a presence and even more so, as well as incongruous, to imagine them using the form of vulnerability expressed in the tactics developed by eco-protesters. Rather, in drawing from the example of French farmers, and stressing the disciplinary strength of his followers Lord Apsley seems to be looking for traditional models of how to express the anger of rural areas. 
.1997b. "What's on in Germany: From Autonomen to Zeitgeist." Do or Die: Voices from Earth First! 6: 109-110. . 1997c. “The Empire Strikes Back.” Do or Die: Voices from Earth First! 6:

$136-142$.

. 1997d. "Why Reclaim the Streets and the Liverpool Dockers?” Do or Die:

Voices from Earth First! 6: 10-11.

1997e. “Reclaim the Streets!” Do or Die: Voices from Earth First! 6: 1-6.

Anon. 1998a. "Gathering Force.” Do or Die: Voices from Earth First! 7: 139-144. . 1998b. "Personality Politics: the Spectacularisation of Fairmile." Do or Die:

Voices from Earth First! 7: 35-37.

. 1998c. "In the Dungeons of Fortress Europe." Do or Die: Voices from Earth

First! 7: 129-131.

. 1998d. "No Escape from Patriarchy: Male Dominance on Site.” Do or Die:

Voices from Earth First! 7: 10-13. . 1998e.“ Green Fort versus Mean Port” Do or Die: Voices from Earth First! 7:

97-99.

Byrne, Paul. 1997. Social Movements in Britain. London: Routledge.

1998. "Nuclear Weapons and CND.” Parliamentary Affairs 51 (3): 424-434.

Carey, Jim. 1995. ”Towers of Strength.” Squall 9: 18-22.

DAM Collective. 1998. Earth First! Direct Action Manual. SWEF: Eugene, OR.

Doherty, Brian. 1998. “Opposition to Road-Building.” Parliamentary Affairs 51 (3): 370-383.

Doherty, Brian. 1999. "Paving the Way: the Rise of Direct Action Against RoadBuilding and the Changing Character of British Environmentalism.” Political Studies, forthcoming. 
Donga, Alex. 1996. "The Rise (and Fall?!) of the Ego-Warrior.” Do or Die 5: 88-89.

Doyle, Timothy. 1994. "Direct Acton in Environmental Conflict in Australia: A ReExamination of Non-Violent Action.” Regional Journal of Social Issues 28: 1-13. Foreman, Dave. and Haywood, Bill. 1987. Ecodefense, Tucson, AZ: Ned Ludd Books.

Hall, Sarah. 1998. "WI Members Transform into Eco-Warriors to Fight Blot on the Landscape." The Guardian. November 24.

Hunt, Heather. 1995. "Balancing Act: Personal Politics and Anti-Roads

Campaigning." Soundings 1: 123-138.

Kriesi, Hans Peter, Koopmans, Ruud, Duyvendak, Jan W., Giugni, Marco G. 1995.

New Social Movements in Western Europe: A Comparative Analysis. London: UCL Press.

McAdam, Doug. 1983. "Tactical Innovation and the Pace of Insurgency." American Sociological Review 48: 735-754. . 1995 “ ‘ Initiator' and 'Spin-Off Movements’: Diffusion Processes in Protest Cycles.” Pp. 217-239 in Repertoires and Cycles of Collective Action, Mark Traugott, ed. Durham, NC: Duke University Press. . 1996. "The Framing Function of Movement Tactics.” Pp. 338-355 in

Comparative Perspectives on Social Movements, Doug McAdam, John McCarthy, and Mayer Zald, eds. Cambridge: Cambridge University Press.

McAdam, Doug and Rucht, Dieter. 1993. "The Cross-National Diffusion of Movement Ideas." Annals of the American Academy of Political and Social Science 528: $56-74$

Maguire, Diarmuid. 1992. "When the Streets Begin to Empty.” West European Politics 15 (4): 75-94. 
McKay, George. 1996. Senseless Acts of Beauty: Cultures of Resistance since the

Sixties. London: Verso.

McKay, George. 1998. “DiY Culture: Notes Towards an Intro.” Pp. 1-53 in DiY

Culture: Party and Protest in Nineties Britain, George McKay, ed. London: Verso.

McLeod, Rhoda. 1998. "Calf Exports at Brightlingsea." Parliamentary Affairs 51 (3):

$345-357$.

Merrick. 1997. Battle for the Trees. Leeds: godhaven ink.

Purkiss, Jonathon. 1996. "Daring to Dream: Idealism in the Philosophy, Organization and Campaigning Strategies of Earth First!” Pp. 197-217 in. To Make Another World: Studies in Protest and Collective Action, Chris Barker and Paul Kennedy, eds.

Aldershot: Avebury.

Road Alert! 1997. Road Raging: Top Tips for Wrecking Roadbuilding. Newbury.

Rochon, Thomas. 1990. Mobilizing for Peace: Anti-Nuclear Movements in Western

Europe. Princeton, NJ: Princeton University Press.

Roseneil, Sasha. 1995. Disarming Patriarchy: Feminism and Political Action at

Greenham. Buckingham: Open University Press.

Rucht, Dieter. 1990. “The Strategies and Action Repertoires of New Movements.' Pp. 156-175 in Challenging the Political Order, Russell Dalton and Manfred Kuechler, eds. Cambridge: Polity.

Seel, Ben. 1997a. "Strategies of Resistance at the Pollok Free State Road Protest Camp.” Environmental Politics 6 (4): 108-139.

Seel, Ben. 1997b. "If Not You, Then Who? Earth First! in the UK." Environmental Politics 6 (4): 172-179.

Tarrow, Sidney. 1994. Power in Movement. Cambridge: Cambridge University Press. 
Tarrow, Sidney. 1995. “Cycles of Collective Action.” Pp. 89-116 in Repertoires and Cycles of Collective Action, Mark Traugott, ed. Durham, NC: Duke University Press. Tilly, Charles. 1995. “Contentious Repertoires in Great Britain, 1758-1834.” Pp. 1542 in Repertoires and Cycles of Collective Action, Mark Traugott, ed. Durham, NC: Duke University Press.

Traugott, Mark. 1995. “Barricades as Repertoire.” Pp. 43-56 in Repertoires and Cycles of Collective Action, Mark Traugott ed. Durham, NC: Duke University Press. Vidal, John. 1998 “Can This Little Lot Really Beat Britain's Nuclear Giant?” The Guardian 28 August.

Vidal, John and Bellos, Alex. 1996. "Protest Lobbies Unite to Guard Rights." The Guardian, 27 August.

Wall, Derek. 1997. The Politics of Earth First! in the United Kingdom. PhD. Thesis, University of West of England. 